\title{
Estimating the cost of bovine tuberculosis at the public and farm levels: The case of Samsun Province, Turkey
}

\author{
Berrin ŞENTÜRK ${ }^{1}$, Aytaç AKÇAY ${ }^{2}$, Savaş SARIÖZKAN³
}

\author{
${ }^{1}$ Ondokuz Mayis University, Faculty of Veterinary Medicine, Department of Livestock Economics and Management, Samsun/TURKEY \\ ${ }^{2}$ Erciyes University, Faculty of Veterinary Medicine, Department of Biometrics, Kayseri/TURKEY \\ ${ }^{3}$ Erciyes University, Faculty of Veterinary Medicine, Department of Animal Health Economics and Management, Kayseri/TURKEY
}

Key Words:

Bovine tuberculosis

farm cost

milk losses

outbreak

public cost

\section{Anahtar Kelimeler: \\ Çiftlik maliyeti \\ kamu maliyeti \\ mihrak \\ sığır tüberkülozu \\ süt kayb1}

Received: 24.12 .2019

Accepted: 22.06.2020

Published Online: 28.08 .2020

Article Code: 660713

Correspondence:

B. SENTÜRK

(bsenturk@omu.edu.tr)

ORCID:

B. ŞENTÜRK : 0000-0002-2540-6491

A. AKCAY : :0000-0001-6263-5181

S. SARIÖZKAN: 0000-0003-2491-5152

\begin{abstract}
In this study, the costs of bovine tuberculosis cases at the public and farm levels were investigated in Samsun Province, Turkey. In determination of the public costs of the disease namely tuberculin costs, transportation costs, expenditure on personnel and the amount of compensation paid, were taken into consideration. In determining the losses due to the disease at the farm level, namely losses of milk and meat and the extra costs of animal replacement, were calculated. For the calculations where the disease was detected, information of outbreak and the breed yield averages of the infected animals were used. In 2016, the public cost of the disease was $¥ 652.780$, with lost milk production valued at $¥ 563.500$, and lost meat production valued at $£ 37.646$ for females and $£ 6.193$ for males. The cost of paid for animal restocking was calculated at $£ 1.052$ per animal. In addition, the total cost of the disease for Samsun Province in 2016 current prices was estimated at $₹ 1.418 .971$ (\$ 403.117).
\end{abstract}

Sı̆̆ır tüberkülozunun kamu ve çiftlik düzeyinde maliyetlerinin tahmini; Samsun ili örneği, Türkiye

\section{ÖZ}

Bu çalışmada, Samsun ilinde, kamu ve çiftlik düzeylerinde sığır tüberkülozu vakalarının maliyeti incelenmiştir. Hastalığın kamu maliyetlerinin belirlenmesinde, tüberkülin maliyetleri, nakil maliyetleri, personel harcamaları ve ödenen tazminat miktarı dikkate alınmıştır. Çiftlik seviyesindeki hastalığa bağlı kayıpların belirlenmesinde, süt ve et kaybı ve hayvan yenilemenin ekstra maliyeti hesaplanmıştır. Hastalığın tespit edildiği işletmeler için yapılan hesaplamalarda, salgın hakkındaki bilgi ve enfekte hayvanların verim ortalamaları kullanılmıştır. Hastalığın 2016 yılı kamu maliyeti 652.780 ₹, kaybedilen süt üretimi değeri 563.500 £, kayıp et üretim değeri dişiler için 37.646 ₹ ve erkekler için 6.193 ₹ olarak hesaplanmıştır. Hayvan yenileme maliyeti hayvan başına 1.052 € olarak hesaplanmıştır. Ayrıca, 2016 yılında Samsun ili hastalığının toplam maliyetinin 2016 fiyatlarıyla 1.418.971 £ (403.117 \$) olduğu tahmin edilmiştir.

\section{INTRODUCTION}

Bovine tuberculosis (bTB) is a zoonotic disease which has many impacts such as public and business costs, loss of foreign trade or problems with that trade, as well as its negative effects on human and animal health. The multi-factor effect of the disease makes the struggle of the disease discussed at the theoretical and economic levels (1). Scientifically, epidemiology and disease management programs in disease control are discussed (2). Calculation of the public costs of the disease varies according to the particular country's disease control efforts, as well as the amount of compensation paid. Compensation payments can vary significantly from between countries, and from year to year, even within the same country, in line with the incidence of the disease and the prevailing political and economic circumstances.

In fact, it is very important to show the extent to which the payments made to the farmer for the regulation of the disease lags behind the costs of the disease and to show the aim of solving the disease with risk-centered epidemiology-oriented and humanoriented approaches. Therefore, the aim of the present study was to estimate the costs of the control of bTB outbreaks and also the direct losses due to the disease in Samsun Province, Turkey in 2016.

\section{MATERIALS AND METHODS}

The data and data sources of the materials used in this study are presented in Table 1. The data were obtained from official records for bTB from January 1 - December 31, 2016 in Samsun Province, Turkey, and the current prices for 2016 were used. In addition, the data for compensation and for the farm animals were obtained from the records of the Ministry of Agriculture and Forestry (Data request; dated 20.01.2017 and numbered 22223993-1838, Data supply; dated 25.01.2017 and dated 21763568-325.01-E.192904) and are expressed as official data (OD). In this study, the costs of bTB at the public and farm levels were calculated as follows:

\section{Estimation of the public costs of the disease}

The public costs of the disease were determined according to the procedures carried out on the disease-confirmed farm.

a. Cost of tuberculin:

Cost of tuberculin injection $=$ Number of tuberculin administrations $\times$ Unit price of dose

b. Transportation costs: 
Table 1 Data used in this study, sources and values for 2016

\begin{tabular}{|c|c|c|}
\hline Data & Data source & Value \\
\hline Raw milk price & $\begin{array}{l}\text { National Dairy } \\
\text { Council* }\end{array}$ & 1.15 (Đ/Liter) \\
\hline Tuberculin price & $\mathrm{CVCRI}^{* *}$ & $2.21(\varsubsetneqq /$ dose $)$ \\
\hline \multirow[t]{3}{*}{ Live animal prices } & $\mathrm{TS} * * *$ & Pure breed: $¥ 5.161$; \\
\hline & & Mixed breed : $€$ 4.015; \\
\hline & & Local breed: $€ 3.126$ \\
\hline Number of staff administering tuberculin & Expert opinion & 2 \\
\hline $\begin{array}{l}\text { Average number of tuberculin administrations } \\
\text { per farm }\end{array}$ & Expert opinion & 4 \\
\hline Carcass meat price & Expert opinion & $22 € / \mathrm{kg}$ \\
\hline $\begin{array}{l}\text { Number of tuberculin administrations at the } \\
\text { provincial level }\end{array}$ & $\mathrm{OD}$ & 1.285 \\
\hline $\begin{array}{l}\text { Number of tuberculin administrations in the } \\
\text { study area }\end{array}$ & OD & 1.096 \\
\hline Fuel price & Socar energy $* * * *$ & 4,76 છ/liter \\
\hline $\begin{array}{l}\text { Number of farms where tuberculin was } \\
\text { administered }\end{array}$ & OD & 25 Unit \\
\hline Minimum veterinary physician pay rate & $\begin{array}{l}\text { TVHB } \\
\text { decision } * * * * *\end{array}$ & 3.300 E /Month \\
\hline Hourly rate for veterinary physician & $\begin{array}{l}\text { Calculation of } \\
\text { expert opinion }\end{array}$ & 毛 13,75 \\
\hline Average number of visits to each farm & $\mathrm{OD}$ & 5 times \\
\hline Average number of hours worked at each farm & OD & $4 \mathrm{~h}$ \\
\hline Cost of compensation (total for study area) & OD & € 550.275 \\
\hline $\begin{array}{l}\text { Cost of compensation (total for Samsun } \\
\text { Province) }\end{array}$ & OD & € 635.238 \\
\hline Gender of slaughtered animals & OD & 134 Female; 17 Male \\
\hline Total number of animals in tuberculin testing & OD & $\begin{array}{c}735 \text { head (491 Female; } 244 \text { Male } \\
\text { ) }\end{array}$ \\
\hline The number of animals bTB positive & $\mathrm{OD}$ & 151 head \\
\hline $\begin{array}{l}\text { In the calculation of loss of milk production, it } \\
\text { was assumed that } 50 \% \text { of } 491 \text { female animals } \\
\text { were milk-bearing and aged } 3 \text { and over. }\end{array}$ & Calculation & $\begin{array}{c}\text { Female animal } \\
\text { number } \times[(\text { Average milk yield } / \\
12) \times 8] \times \text { milk price }\end{array}$ \\
\hline Reduced meat yield (in all cattle) & Expert opinion (8) & $\% 6-12$ \\
\hline Cost of replacement & $\begin{array}{l}\text { Expert Opinion } \\
(2,8)\end{array}$ & $\% 15-46$ the value of animal \\
\hline Data & Data source & Value \\
\hline
\end{tabular}

* (Anonymous a 2016); ** (Anonymous b 2016); *** Turkish Statically Institute; ****( Anonymous c 2016); ***** (Anonymous d 2016)

The cost of administration of tuberculin was calculated as the cost of return travel to farms for the evaluation of the results of tuberculin testing. Since tuberculin administration in the villages of the study area constituted $85 \%$ of all the administrations, these villages were used for the determination of round trip distance.

In calculating transportation costs, the following formula was employed:

Number of visits to farms for tuberculin administration and evaluation of results $\times$ average round trip distance to the farm $\times$ the number of farms on which tuberculin testing was performed.
Transport cost $=($ Total roundtrip distance to farms for the tuberculin applications and evaluation of the results) $\times 8 / 100$

The distances between the villages with the disease and the centers to which they are connected were calculated and it was found average $10.2 \mathrm{~km}$ for per village distance.

c. Labor / Service costs:

Minimum veterinary costs were determined by using the minimum monthly salary of $€ 3.300$ (Turkish Veterinary Association Decision) for 2016 (7). 
Total working time $=$ (Number of farms where the disease was detected $) \times($ average number of trips to farms $) \times($ average number of veterinarians sent to farms) $\times$ (average working time of the veterinarian on each farm)

\section{d. Cost of compensation:}

Official data was used as the compensation cost. Accordingly, the total public cost of the disease was calculated as the sum of the items: (Cost of administering tuberculin) +(Transportation costs) + (Labor / Service cost $)+($ Cost of compensation)

\section{Losses at farm level (direct losses)}

According to official data, on farms where bTB was detected, there were 134 female cattle and 17 male cattle. Documentation of these groups is essential for compensation payments. For this reason, animals that were determined to be positive in the outbreaks and subject to compensation were divided into three groups. Groups were as follows: 3 years of age (71 head), 3-8 years of age (78 head) and above 8 years of age ( 2 head), respectively. In order to determine the losses of meat and milk, it is necessary to know the breeds of animals subject to compensation. In the study area, 5 different cattle breeds were confirmed (OD), namely 103 Holstein (68.2\%), 20 Simmental $(13.2 \%)$, 14 Jersey $(9.3 \%) 9$ Yerli Kara (Local) $(6.0 \%)$ and 5 Brown Swiss $(3.3 \%)$. In determining the direct losses of the disease at the farm level, milk and meat production losses and the cost of replacement were used. Data on livestock prices were obtained from TurkStat (5)

a. Calculation of milk loss: On the farms where the disease is wasted, the milk of the animals is destroyed. The milk of cows infected with bTB is legally unsalable. For this reason, the estimated milk loss was calculated by assuming that $50 \%$ of the total number of female animals on the farms with confirmed bTB cases was of milking age. In the calculation of milk loss, 8 months loss of production was adopted as the standard because the infected animals remain under quarantine for a total of 8 months.

In determining the milk yield in the study area, the annual average milk yields of the infected pure breed, hybrid and local breed animals were taken into consideration and the loss of value was calculated by using the 2016 milk price. The yields of breeds used in the calculation of milk and meat loss are presented in Table 2. b. In the calculation of meat loss:

In the calculation of meat loss, live weight loss and related meat loss were calculated on the basis that males and females lost approximately $6 \%$ of their live weight using the expert opinion results and literature (8). For the calculation of the losses of meat production, the weights by gender for the determined breeds (as stated in the legislation) are calculated for Average Female Slaughter Weight $(387 \mathrm{~kg}$ ) and Average Male Slaughter Weight $(460 \mathrm{~kg})$ which is calculated Holstein, Simmental, Jersey, Brown Swiss and Local breed (10-12) with the meat yield from female animals being $55 \%$ and from male animals being $60 \%$.

The weight loss of male and female cattle on the farm was calculated from the average of the live weights of bTB positive animals on the farm, as follows;

Weight loss of female animals $=$ Average live weight $\times$ Number of female animals and dressing percentage is $55 \%$ in accordance with the legislation (OD). The price of meat that was adopted was $€ 22$ / $\mathrm{kg}$ (expert opinion; red meat producers' union members).

c. The cost of replacement: The total amount of compensation paid to the animal's owner on the basis of expert opinion was calculated by adding up to $25 \%$ of the base value of the animal to the compensation amount/animal, i.e.,

Total amount of compensation paid / number of animals paid compensation for $=$ animal's value $+($ value of animal $/ 4)$

The cost of the disease at the operating/producer level was calculated as; milk loss + meat loss + animal replacement cost. Finally, the total cost of the disease outbreak was obtained by summing all the costs calculated at public and business level.

\section{RESULTS}

The findings of this study on bTB were based on public and farm level expenditures.

Public cost of bTB: The public cost of the disease was calculated according to the procedures of the official institutions following the end of the outbreak (2). The cost items and cost amounts are given in Table 3.

Table 2. Dairy breeds and their annual production characteristics in Samsun Province, Turkey

\begin{tabular}{|c|c|c|c|}
\hline Breed & Number (head) & $\begin{array}{l}\text { Average annual } \\
\text { milk yield }\end{array}$ & Slaughter weight \\
\hline Holstein* & 103 & $3.500 \mathrm{~L}$ & Female $450-500 \mathrm{~kg}$, male $550-600 \mathrm{~kg}$ \\
\hline Simmental* & 20 & $4.000 \mathrm{~L}$ & Female $500-550 \mathrm{~kg}$, male $600-650 \mathrm{~kg}$ \\
\hline Jersey* & 14 & $2.800 \mathrm{~L}$ & Female $300-320 \mathrm{~kg}$, male $300-350 \mathrm{~kg}$ \\
\hline Yerli Kara (local) & 9 & $1.200 \mathrm{~L}$ & $200-250 \mathrm{~kg}$ \\
\hline Brown Swiss* & 5 & $3.500 \mathrm{~L}$ & Female $400-450 \mathrm{~kg}$, male $500-550 \mathrm{~kg}$ \\
\hline
\end{tabular}

*Average milk production of breed and mixed breed animals.

The following formulas were used in the calculation:

Amount of milk loss

$(8$ months, $\mathrm{L})=[($ Average milk yield $/ 12) \times 8]$

Loss of milk production calculated with this formula:

Lost milk production (€) =Average eight-month milk yield loss on farm (L) $\times$ Milk price (も) $\times$ number of dairy cattle
Losses at the farm level due to bovine tuberculosis (direct losses): The losses due to the disease at the farm level are presented in Table 4. According to the information given above, the mean total cost per quarantined farm of bTB based on 2016 data in Samsun Province was $€ 652.780+766.158=€ 1.418 .938$. The losses of live weight and meat losses are presented in Table 5.

Total cost of the bTB outbreak: The total cost of the bTB outbreak based on the losses at the farm level and the public cost, was $€ 652.780+€ 766.158=€ 1.418 .938$. 
Table 3. Public expenditure on the outbreak of bovine tuberculosis in Samsun Province in 2016

\begin{tabular}{lc}
\hline Cost items (£) & Public cost of bTB (€) \\
\hline 1.1.a.Tuberculin costs & 2.840 \\
1.1.b.Transportation costs & 952 \\
1.1.c. Labor/service costs & 13.750 \\
1.1.d. Compensation costs & 635.238 \\
Total Costs (a+b+c+d) & 652.780 \\
Average public cost per farm & 26.111 \\
\hline
\end{tabular}

Table 4. Farm level losses due to bTB in Samsun Province, Turkey in 2016 Cost items (Đ)

The general mean loss due to the disease at the farm level (£)

2.2.a. Value of lost milk 563.500 production (‡)

2.2.b. The value of meat

production loss of male cattle (も)

2.2.c. The value of meat

production loss of female cattle (‡)

2.2.d. Extra cost of animal 158.818 replacement (£)

Total cost $(a+b+c+d)$ 766.158 the second highest at $€ 13.750$. The cost of transportation, tuberculin and its administration was very low $(1 \%)$. This is due to the fact that the cost of transportation to the provincial directorates is not taken into consideration in the calculation of transportation costs and the calculations of compensation and tuberculin applications are made per animal. Moreover, the calculation of transportation expenses is based on the number of outbreaks.

In a study that evaluated the economic effects of bTB cases in the UK, the cost of testing per animal on a cattle fattening farm was between $f, 1.95$ and $f, 2.97$ (9). In the present study, the unit price per tuberculin dose for 2016 was $€ 2.21$. Tuberculin was included in the cost calculations in the UK but the administration is carried out free of charge by the relevant Ministry in Turkey. The price difference is therefore due to the price differences of the administration of tuberculin and tuberculin itself. In the UK, the cost of restrictions on animal movements varied from $£, 3,198$ to $£, 55,000$ for the eight case study farms (2). However, the general tendency of the producers in Turkey is to leave the costs, such as litter and extra workmanship, out of the costing. Regarding biosafety measures, for example, extra fencing around the enterprise, isolation of sick animals and the increased need for water for cleaning are not considered in practice, but all of these would increase the costs attributable to the disease. Therefore, only the estimated minimum costs of the disease were used. In future studies on bTB, more accurate results would be obtained by using observations on farms used for breeding and stocking.

In this study, the losses at the farm level were: milk (₹ 563.500), meat (£ 3.839) and animal replacement (£ 158.818). According to the legal statutes, all milk should be disposed of at the enterprises that are infected/under disease notice (13). In the present study, the animals detected with the disease were dairy cattle and the milk was destroyed.

Table 5. Farm level losses due to bTB in Samsun Province, Turkey in 2016

\begin{tabular}{lcc}
\hline Data & Female & Male \\
\hline Average slaughter weight $(\mathrm{kg})$ & $387(\mathrm{a})$ & $460(\mathrm{~b})$ \\
Dressing percentage $(\%)$ & 55 & 60 \\
Number of animals & $134(\mathrm{c})$ & $17(\mathrm{~d})$ \\
Live weight price $(€ / \mathrm{kg})$ & 22 & 22 \\
Live weight cost 6\% (29) & $(\mathrm{a} \times \mathrm{c}) / 100 \times 60=310.908$ & $(\mathrm{~b} \times \mathrm{d} / 100 \times 6$ \\
Live weight loss per animal, kg & 23,22 & 27,6 \\
Mean meat loss per animal $(\mathrm{kg})$ & 12,77 & 16,56 \\
Mean meat loss value per & 280,94 & 364,32 \\
animal (£) & & \\
Total meat loss value (£) & $12,77 \times 2234=37.646$ & $16,56 \times 22 \times 17=6.193$ \\
\hline
\end{tabular}

\section{DISCUSSION AND CONCLUSION}

In this study, the outbreak of bTB in Samsun Province caused a minimum loss of $£ 1.418 .938$, based on the prices in 2016. In addition, the cost of the disease to the public was $£$ 652.780. That meant $46 \%$ of the total cost was a public cost, while the remaining $54 \%$ was incurred by the producers in the private sector. These calculated figures were only for Samsun Province, suggesting that the costs of the disease across the 81 provinces in Turkey would be very much higher.

In this study, the cost of compensation constituted a significant portion of public costs $(97 \%)$, while the veterinary costs $(2 \%)$ were
Therefore, milk loss represented the highest loss at the enterprise level. In this study, approximately $2 / 3$ of the animals with the disease were female. This is due to the fact that animal husbandry on farms is mainly composed of mixed structure enterprises to obtain calves. This situation suggests that biosecurity measures should be increased on dairy cattle farms and animal welfare criteria should be applied. On the other hand, the high level of losses due to the disease in dairy farming requires more attention due to the high probability that the disease will be transmitted to the offspring through the milk (the digestive form of the disease) (14).

Increasing the awareness of farm managers is of great importance. 
While a breeder with a large number of animals experiences heavy losses, owners/managers of small-scale enterprises generally do not grasp the seriousness of the disease due to its infectivity and do not scrupulously implement health and quarantine measures. The sometimes less professional approaches of the small enterprise mangers include hesitating about the destruction of milk. The lack of training of the breeders combined with matters of commercial interest lead to concerns about human health.

This study determined high costs of the disease, even for calculations made at the minimal cost levels for both the public and private sectors. This situation increases concerns about both human and animal health in the future. Programs to combat bTB in cattle in Turkey, including animal movement restrictions, are only implemented at the farm level when the disease status is confirmed. These measures can cause significant commercial losses in the short and long term due to the establishment of the disease. However, the negative impact of these farms on other farms cannot be calculated into the future. In Turkey, especially in the villages, dairy farms are normally in close proximity to each other which increases the risk of the spread of epidemics. Since animal movements are limited to the farm affected by the disease, while neighboring enterprises may be at high risk of infection by the disease, no measures are taken by these enterprises. Disease intervention measures should be developed for the enterprises that are close to the infected farms, and sales of animals and animal products should be regulated. Cattle farms in Turkey are generally small-scale, family farms that sell milk, yogurt and butter, the latter two of which have not been taken into account in the current calculations. In terms of short-term financial losses, it is estimated that the losses to farmers could actually be considerably higher than stated here.

In conclusion; Disease eradication programs are an important part of consumer and producer welfare. Disease protection measures applied in the most developed countries should be examined carefully, and measures that contribute to improved disease control, including cost-benefit analyses, should be applied.

Currently, there is not enough attention given to issues such as the destruction of feed and suspect materials, the disinfection of instruments and equipment, and the separation of sick animals and the management of their health and welfare, including feeding. In addition, the extra feed, labor and fencing costs incurred by farmers should be repaid to them. Taking a series of additional measures would considerably increase the effectiveness of the current control policies and protection strategies implemented.

\section{ACKNOWLEDGEMENT}

The authors thank Gregory T. Sullivan for helpful comments and for editing the English in an earlier version of this manuscript.

\section{REFERENCES}

1. Ray A. Estimation of the Economic Burden of Tuberculosis in India, Acta Scientific Medical Science. 2018; 2 (8).

2. Sheehy SJ, Christiansen KH. Cost/benefit analysis of Irish bovine tuberculosis eradication scheme. Dublin, University College Dublin. 1991; 79 .

3. Anonymous a. National Dairy Council, Raw Milk Prices, Milk Prices.2016

4. Anonymous b. Veterinary Biological Product Selling Price, Bovine Tuberculin PPD, Etlik Central Veterinary Control and Research Institute. 2016.
5. Turkish Statical Institute. Livestock and Animal Product, Prices and Production Value. 2016.

6. Anonymous c. Fuel Price, Socar energy. 2016

7. Anonymous a. Veterinary Physician Fees, the Decision of Turkish Veterinary Medical Association. 2016.

8. Meisinger G. Untersuchungen über die ökonomischen Auswirkungen der Rinder tuberkulosetilgung auf die Produktivität der Rinderbestände, 1. Mitteilung: Auswirkung auf die Milchproduktion, Münchener Tierrztliche Wochenschrift, 1969; pp. 806-809.

9. Butler A, Lobley M, Winter M. Economic Impact Assessment of Bovine Tuberculosis in the South West of England, University of Exeter, CRPR Research Paper, No 30, 2010.

10. Alpan O, Aksoy AR. Cattle breeding and fattening, 7th edition. Favori Printing \& Publishing San. Tic. Ltd. Sti, Uskudar, Uskudar, Istanbul. 2015; pp.33-5.

11. Alpan O. Cattle Breeding and Breeding, Çamlı Livestock, İzmir. 1992; pp.39.

12. Tiknazoğlu B. Cattle breeding, Samsun Provincial Directorate of Agriculture, Farmer Education and Extension Branch Publication, Samsun.2010.

13. Official Gazzete (2009): Cattle Bovine Tuberculosis Regulation, (27188, 2 Nisan/2009).

14. Radostits OM, Blood DC, Gay CC. Veterinary Medicine A Textbook of the Diseases of Cattle, Sheep, Pigs, Goats and Horses Eighth Edition, W.B. Saunders, London, UK. 1990. (ISSN: 0-70201592-X.) 